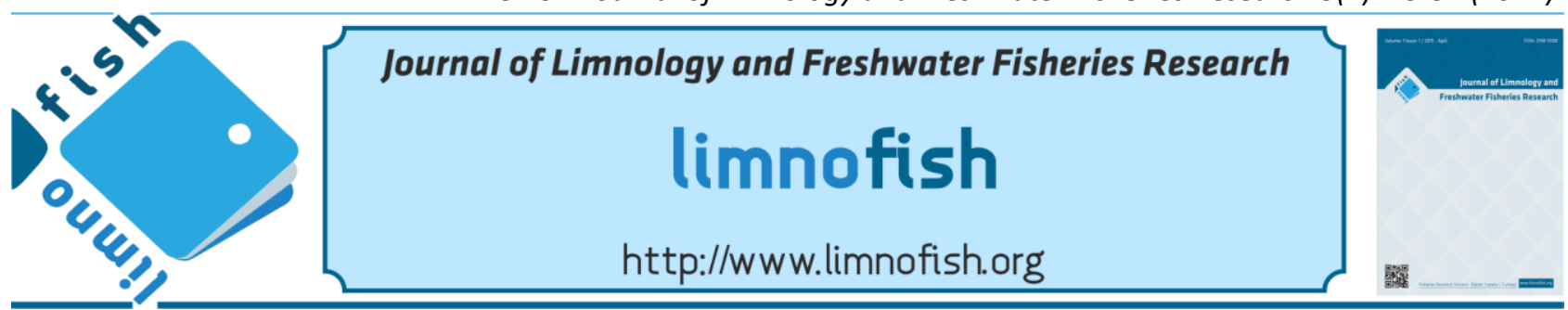

\title{
Effect of Different Straw Volumes and Thawing Rates on Post-Thaw Quality and Fertilization Ability of Cryopreserved Common Carp (Cyprinus carpio) Sperm
}

\author{
Yusuf BOZKURT ${ }^{1, *}$, illker YAVAŞ ${ }^{2}$ \\ ${ }^{1}$ Iskenderun Technical University, Faculty of Marine Sciences and Technology, Iskenderun, Hatay, Turkey \\ ${ }^{2}$ Mustafa Kemal University Faculty of Veterinary Medicine, Antakya, Hatay, Turkey
}

\section{A B STRACT}

Cryopreservation of sperm cells is an essential process applied for long-term conservation of aquatic genetic resources. The goal of this research was to determine effect different of straw volumes and thawing rates on the postthaw quality and fertilization ability of cryopreserved common carp (Cyprinus carpio) sperm. In this study, semen was cryopreserved according to conventional slow freezing protocol. For this aim, the cryosolution contained $75 \mathrm{mM} \mathrm{NaCl}, 70 \mathrm{mM} \mathrm{KCl}, 2 \mathrm{mM} \mathrm{CaCl} 2,1 \mathrm{mM} \mathrm{MgSO} 4$ and $20 \mathrm{mM}$ Tris (pH: 8) supplemented with $10 \% \mathrm{MeOH}$. Following equilibration at $+4{ }^{\circ} \mathrm{C}$ for $10 \mathrm{~min}$, semen was packed into $0.25,0.5$ and $1.5 \mathrm{~mL}$ straws and frozen in liquid nitrogen vapour (for $10 \mathrm{~min}$ at $-120^{\circ} \mathrm{C}$ ) and finally stored in liquid nitrogen $\left(-196{ }^{\circ} \mathrm{C}\right)$ tank. Thawing of cryopreserved semen process was performed at $30{ }^{\circ} \mathrm{C}$ for 10,20 and 30 seconds in a water bath. Fertilization was performed using a ratio of $1 \times 10^{5}$ spermatozoa/egg. The highest fertility $(68.4 \pm 2.5 \%)$ was determined with cryopreserved sperm packed in $1.5 \mathrm{~mL}$ straws that thawed at $30{ }^{\circ} \mathrm{C}$ for $30 \mathrm{~s}$. According to the results of this research, sperm cryopreserved with ionic extender containing $10 \%$ methanol and packed in $1.5 \mathrm{~mL}$ straws are suitable to achieve high fertilization of common carp eggs.

Keywords: Cyprinus carpio, cryopreservation, spermatozoa motility, straw volume, thawing rate.

\section{ARTICLE INFO}

RESEARCH ARTICLE

Received : :14.12.2016

Revised : :05.03.2017

Accepted : 08.03.2017

Published : 24.04.2017

DOI: 10.17216/LimnoFish.277835

* CORRESPONDING AUTHOR

yusuf.bozkurt@iste.edu.tr

Tel : +903266141693

Farklı Payet Hacmi ve Çözdürme Oranlarının Dondurulmuş Sazan (Cyprinus carpio) Spermasının Çözüm Sonu Kalitesi ve Fertilizasyon Yeteneği Üzerine Etkisi

Öz: Sperm hücrelerinin kriyoprezervasyonu, akuatik genetik kaynaklarının uzun süreli korunumu için uygulanan bir işlemdir. $\mathrm{Bu}$ araştırmanın amacı; farklı payet hacimlerinin ve çözdürme oranlarının dondurulan sazan (Cyprinus carpio) spermasının çözüm sonu kalite ve fertilizasyon yeteneği üzerine olan etkisini belirlemektir. $\mathrm{Bu}$ çalışmada sperma, konvansiyonel yavaş dondurma protokolüne göre dondurulmuştur. $\mathrm{Bu}$ amaçla kullanılan kriyosolüsyon $75 \mathrm{mM} \mathrm{NaCl}, 70 \mathrm{mM} \mathrm{KCl}$, $2 \mathrm{mM} \mathrm{CaCl} 2,1 \mathrm{mM} \mathrm{MgSO} 4$ and $20 \mathrm{mM}$ Tris (pH: 8) ve $\% 10 \mathrm{MeOH}$ içermiştir. $+4{ }^{\circ} \mathrm{C}$ ' de $10 \mathrm{dk}$. Ekilibrasyon işlemini takiben sperma $0,25,0,5$ ve $1,5 \mathrm{~mL}$ 'lik payetler içerisinde sıvı azot buharında $\left(-120{ }^{\circ} \mathrm{C}\right.$ 'de $\left.10 \mathrm{dk}\right)$ dondurularak sivı azot tankında $(-196 \mathrm{oC})$ depolanmıştır. Dondurulan spermanın çözdürme işlemi su banyosunda $30^{\circ} \mathrm{C}^{\prime} \mathrm{de} 10,20$ ve $30 \mathrm{~s}$ süre ile gerçekleştirilmiştir. Fertilizasyon işlemi 1x105 spermatozoa/yumurta oranında uygulanmıştır. En yüksek fertilizasyon, $1,5 \mathrm{~mL}$ payetlerde dondurulan ve $30{ }^{\circ} \mathrm{C}$ 'de 30 s'de çözdürülen grupta $\% 68,4 \pm 2,5$ oranında tespit edilmiştir. $\mathrm{Bu}$ araştırmanın sonuçlarına göre sazan yumurtalarının döllenmesinde $\% 10$ oranında methanol içeren sulandırıcıda 1,5 mL payetler içerisinde dondurulan sperma kullanılması yüksek fertilizasyon elde edilebilmesi açısından uygundur.

Anahtar kelimeler: Cyprinus carpio, kriyoprezervasyon, spermatozoa motilitesi, payet hacmi, çözdürme oranı.

How to Cite

Bozkurt Y, Yavaş I. 2017. Effect of Different Straw Volumes and Thawing Rates on Post-Thaw Quality and Fertilization Ability of Cryopreserved Common Carp (Cyprinus carpio) Sperm. LimnoFish. 3(1): 25-31. doi: 10.17216/LimnoFish.277835 


\section{Introduction}

In aquaculture, cryopreservation offers many benefits such as preservation of aquatic genetic diversity, selective breeding, hybridization and supply of gametes for hatchery production or laboratory researches. (Suquet et al. 2000). For this reason, effective sperm cryopreservation procedure has been adviced to the aquaculture sector to improve their culture techniques (Liu et al. 2010).

During cryopreservation, some important factors may change physiological structure of the semen. These factors are: cryoprotectants and their concentrations, extender compositions, dilution ratios, equilibration periods and freezing/thawing rates (Glogowski et al. 1999; Tekin et al. 2007). However, these factors require development of species-specific cryopreservation protocol (Lahnsteiner et al. 1996).

Despite many studies carried out on gamete preservation and also significant findings determined in small-scale laboratory experiments, transfer of this biotechnological technique to the commercial scale applications have many problems. One of the important problems is handling of large quantities of sperm. Packaging of sperm in traditional $0.25 \mathrm{~mL}$ straws have been successfully applied to cryopreservation of sperm and to fertilize small egg batches (Cruz-Casallas et al. 2004). On the other hand, packaging of sperm in small quantities make it ineffective for use in commercial scale production. One of the possible solutions for this problem is using of larger straws. Large straws can decrease the time required for semen packaging and thawing. In addition, it can accelerate sperm manipulations during fertilization (Cabrita et al. 2001).

Extender composition and cryoprotectant types are the main factors affecting cryopreservation success (De Graaf and Berlinsky 2004). Extenders are required for dilution of fish sperm prior to cryopreservation and are generally designed to be compatible with the physiochemical composition of the fish seminal plasma. Most important function of the extenders is to maintain the spermatozoa in immotile state until required (Omitogun et al. 2010). Cryoprotectants are added to the extenders to protect the cells against ice crystal formation during freezing and thawing (Lahnsteiner et al. 1996). Although cryoprotectants help to the prevention of cryoinjuries during freezing and thawing, they may become toxic to the cells when exposure time and concentration are increased (Bozkurt et al. 2005). Thus, one of the most critical steps in successful cryopreservation of fish semen is the choice of cryoprotectant in the extender during the process. In this concept, methanol has been used as permeable cryoprotectant widely for cryopreservation of sperm from different species such as African catfish (Clarias gariepinus) (Steyn and Van Vuren 1987), tilapia (Sarotherodon mossambicus) (Rana and McAndrew 1989), bagrid catfish (Mystus nemurus) (Muchlisin et al. 2004), silver carp (Hypophthalmichtys molitrix) (Alvarez et al. 2003), mahseer (Tor khudree) (Basavaraja and Hegde 2004), tench (Tinca tinca) (Rodina et al. 2007), and salmonid fish (Lahnsteiner et al. 1997).

Consequently, before starting of sperm cryopreservation, fully assessment of different extenders, cryoprotectants, straw volumes, freezing/thawing rates are necessary in order to improve optimal cryopreservation procedures for different fish species in aquaculture. While evaluating the efficacy of the cryopreservation procedure, it is essential to determine post-thaw sperm quality for their capability to fertilize the eggs successfully (Stoss and Holtz 1983). In addition, sperm motility has been regarded as main sperm quality parameter of cryopreservation protocol in order to prevent poor semen quality before freezing and also to detect fertility of frozen sperm following thawing. Also, significant relation between motility and fertilization has been assumed by several authors (Linhart et al. 2000; Akçay et al. 2004).

To the best of our knowledge, there is limited information regarding role of straw volumes on cryopreservation of common carp sperm. From this point of view, this research was carried out to examine the effect of various straw volumes $(0.25$, 0.5 and $1.5 \mathrm{~mL}$ ) and also to test the effect of various thawing conditions on post-thaw sperm quality and fertilization capability of cryopreserved common carp (Cyprinus carpio) sperm.

\section{Material and Methods \\ Broodstock management and gamete collection \\ Experiments were carried out at the State} Hydraulic Works (SHW) Fish Production Station in Adana, Turkey. Broodstock were held in earthen ponds under natural photoperiod cycle. The water temperature varied $23-25^{\circ} \mathrm{C}$ during spawning season. The broodstock were fed daily with pelleted feed and $48 \mathrm{~h}$ prior to stripping, feeding was stopped. Mature male and female fish were gathered from the wintering ponds by catching and transported to the hatchery $48 \mathrm{~h}$ prior to gamete collection. In the hatchery, male and female broodfish were held separately in shaded $1000 \mathrm{~L}$ tanks provided with well-aerated water $(2.5 \mathrm{~L} / \mathrm{min})$ at $24^{\circ} \mathrm{C}$.

Before stripping, broodfish were taken out from the water and their genital openings were wiped in order to dry. In the next step, broodfish were anesthetized in $5 \mathrm{ppm}$ quinaldine solution (Merck). 
Spermiation and ovulation were induced with intraperitoneally injection of carp pituitary extract (CPE). Sperm was collected from 15 mature males by manual abdominal stripping $12 \mathrm{~h}$ after a single injection of $2 \mathrm{mg} / \mathrm{kg}$ of $\mathrm{CPE}$ at $24{ }^{\circ} \mathrm{C}$ water temperature. Care was taken to avoid contamination with urine, mucus, feaces, or water. Then, sperm containing tubes were placed into styrofoambox containing crushed ice $\left(4^{\circ} \mathrm{C}\right)$. Sperm was transferred to the laboratory within $15 \mathrm{~min}$. Eggs were collected from two females by hand stripping 10-12 $\mathrm{h}$ after a double injection of $3.5 \mathrm{mg} / \mathrm{kg}$ of CPE. The first injection, $10 \%(0.35 \mathrm{mg} / \mathrm{kg})$ CPE was given $12 \mathrm{~h}$ before the second $(3.15 \mathrm{mg} / \mathrm{kg})$. For egg collection, females were stripped by abdominal massage and the eggs were collected into a dry metal box.

\section{Sperm quality evaluation}

Spermatozoa motility was determined using a lightmicroscope (Olympus, Japan) at a 400x magnification. Sperm cells were activated by mixing $1 \mu \mathrm{L}$ of sperm with $10 \mu \mathrm{L}$ activation solution $(0.3 \%$ $\mathrm{NaCl}$ ) on a glass slide. Motility determinations were carried out within 10 seconds following activation. Spermatozoa motility was determined with three replicates. For cryopreservation, sperm samples showing below $80 \%$ motility were excluded. Spermatozoa motility duration was determined using a chronometer (sensitivity:1/100 s).

For the aim of spermatozoa density determination, sperm was diluted at ratio of 1:1000 with Hayem solution $\left(5 \mathrm{~g} \mathrm{Na}_{2} \mathrm{SO}_{4}, 1 \mathrm{~g} \mathrm{NaCl}, 0.5 \mathrm{~g}\right.$ $\mathrm{HgCl}_{2}, 200 \mathrm{~mL}$ bicine). Spermatozoa density was calculated with a $100 \mu \mathrm{m}$ deep Thoma haemocytometer (H-100, Hecht-Assistent, Sondheim, Germany) at 400x magnification with Olympus Bx50 phase contrast microscope (Olympus, Japan) and indicated as spermatozoa $\times 10^{9} / \mathrm{mL}$ (three replicates). Sperm $\mathrm{pH}$ was determined with indicator papers (Merck, 5.5-9).

Micro-haematocrit capillary tubes were used for spermatocrit determination. The volume (length) of semen in capillaries was measured by meter scale in $\mathrm{mm}$ and centrifuged for $10 \mathrm{~min}$ at $4000 \mathrm{rpm}$ (3370 $\mathrm{xg}$ ). Spermatocrit described as the percentage volume of white packed cells to the total volume of semen and determinations were done in triplicate for each sample.

\section{Sperm cryopreservation and thawing techniques}

For cryopreservation, selected sperm samples (showing $>80 \%$ motility) were pooled and diluted at a ratio of 1:5 with extender containing following composition: $75 \mathrm{mM} \mathrm{NaCl}, 70 \mathrm{mM} \mathrm{KCl}, 2 \mathrm{mM} \mathrm{CaCl}_{2}$ $1 \mathrm{mM} \mathrm{MgSO} 4,20 \mathrm{mM}$ Tris and $\mathrm{pH}$ was 8.0
(Lahnsteiner et al. 1998). The extender also contained $10 \%$ methanol as an internal cell cryoprotectant. Following 10 min equilibration at 4 ${ }^{\circ} \mathrm{C}$, the diluted sperm was packed into different straw volumes such as $0.25,0.5$ and $1.5 \mathrm{~mL}$ (IMV, France) and were closed with polyvinyl alcohol (PVA). In the next step, the straws were located on a floating rack on the surface of liquid nitrogen in a styrofoam box. The straws were frozen in liquid nitrogen vapour (about $-120^{\circ} \mathrm{C}$ ) $4 \mathrm{~cm}$ above of the liquid nitrogen surface for $10 \mathrm{~min}$. In the next step, the straws were plunged into liquid nitrogen $\left(-196^{\circ} \mathrm{C}\right)$ and stored two weeks. For thawing, the straws were warmed by plunging the straws into water bath at $30^{\circ} \mathrm{C}$ for 10 , 20 and 30 s. Spermatozoa motility and motility durations were determined following activation of sperm with $0.3 \% \mathrm{NaCl}$ after thawing.

\section{Fertilization}

With the aim of fertilization, egg samples (100 eggs) obtained from five females were inseminated in dry petri dishes with cryopreserved or fresh sperm at spermatozoa:egg ratio of $1 \times 10^{5}: 1$. Following $1 \mathrm{~min}$ of incubation of eggs, $100 \mathrm{ml}$ Woynarovich's solution ( $4 \mathrm{~g} \mathrm{~L}^{-1} \mathrm{NaCl}, 3 \mathrm{~g} \mathrm{~L}^{-1}$ urea) was added in order to prevent stickiness of eggs. The dishes were left untouched for $1 \mathrm{~h}$ and the eggs transferred to the Zuger glass incubators. Fertilization ratio was determined under a stereo microscope when the fertilized eggs developed to the gastrula phased embryo.

\section{Data analysis}

Repeated analysis of variance (ANOVA) was implemented to determine differences between parameters. Multiple comparison test (Duncan) for post-hoc comparisons at the level of $\alpha=0.05$ was carried out for the significant means using SPSS 10 for Windows Statistical Software Package.

\section{Results}

In the present research, semen volume was determined higher than $5 \mathrm{~mL}$ and motility was ranged from 75 to $90 \%$. Motility period fluctuated between 39 and $116 \mathrm{~s}$, while the sperm density varied between $14.2 \times 10^{9}$ and $29.5 \times 10^{9}$ spermatozoa $/ \mathrm{mL}$. Spermatocrit value was determined ranging from 17 to $36 \%$ with an avarage of $27.5 \pm 2.49 \%$. The mean $\mathrm{pH}$ value was determined as $7.54 \pm 1.26$. The physical characteristics of fresh semen are summarized in Table 1.

Mean post-thaw motility of common carp sperm was $61.9 \pm 1.8 \%$ while the best motility was determined as mean $75.2 \pm 1.5 \%$. Sperm cryopreserved in $1.5 \mathrm{~mL}$ straws showed the highest post-thaw motility. The highest post-thaw motility 
period was determined as $52.6 \pm 1.4 \mathrm{~s}$ with cryopreserved sperm thawed at 30 second at $30{ }^{\circ} \mathrm{C}$ in $0.5 \mathrm{~mL}$ straws. On the other hand, thawed sperm in $0.25 \mathrm{~mL}$ straws for 10 second at $30^{\circ} \mathrm{C}$ showed the lowest motility duration as $15.2 \pm 2.3 \mathrm{~s}$. The overall mean fertilization rate was determined as $51.9 \pm 2.1 \%$ while the best fertilization rate was determined as mean $68.4 \pm 2.5 \%$ with thawed sperm at $30^{\circ} \mathrm{C}$ for 30 second in $1.5 \mathrm{~mL}$ straws. Spermatozoa motility and fertilization ratio of frozen common carp sperm was statistically different between the experimental groups ( $\mathrm{p}<0.05$; Table 2$)$.

Table 1. Fresh sperm quality properties of male common carp (Cyprinus carpio) broodstock $(\mathrm{n}=15)$.

\begin{tabular}{|c|c|c|c|c|}
\hline Sperm Quality Parameters & Minimum & Maximum & Mean & SD \\
\hline Volume (ml) & 6.2 & 20.5 & 14.37 & 1.46 \\
\hline Motility (\%) & 75 & 90 & 82.86 & 2.27 \\
\hline Movement period (s) & 39 & 116 & 97.32 & 2.15 \\
\hline Density $\left(\mathrm{x} 10^{9} / \mathrm{ml}\right)$ & 14.2 & 29.5 & 25.49 & 3.48 \\
\hline Total density $\left(\mathrm{x} 10^{9}\right)$ & 88.04 & 604.75 & 437.25 & 3.21 \\
\hline Spermatocrit $(\%)$ & 17 & 36 & 27.5 & 2.49 \\
\hline $\mathrm{pH}$ & 6.8 & 8.2 & 7.54 & 1.26 \\
\hline
\end{tabular}

Table 2. Effect of different straw volumes and thawing rates on motility of spermatozoa and fertilization of eggs with cryopreserved sperm in common carp (Cyprinus carpio).

\begin{tabular}{|c|c|c|c|c|c|}
\hline $\begin{array}{c}\text { Straw } \\
\text { Volume } \\
(\mathrm{ml})\end{array}$ & \multicolumn{2}{|c|}{$\begin{array}{c}\text { Thawing } \\
\text { Rate } \\
\left({ }^{\circ} \mathrm{C}\right)(\mathrm{s})\end{array}$} & $\begin{array}{c}\text { Post-thaw } \\
\text { Motility } \\
(\%)\end{array}$ & $\begin{array}{l}\text { Post-thaw } \\
\text { Mot. Per. } \\
\text { (s) }\end{array}$ & $\begin{array}{c}\text { Fertilization } \\
\text { Rate } \\
(\%)\end{array}$ \\
\hline 0.25 & 30 & 10 & $60.2 \pm 1.4^{\mathrm{c}}$ & $15.2 \pm 2.3^{\mathrm{a}}$ & $45.2 \pm 3.6^{\mathrm{b}}$ \\
\hline 0.25 & 30 & 20 & $55.3 \pm 1.2^{\mathrm{b}}$ & $37.5 \pm 1.4^{\mathrm{cd}}$ & $47.4 \pm 2.8^{\mathrm{bc}}$ \\
\hline 0.25 & 30 & 30 & $60.5 \pm 2.7^{\mathrm{c}}$ & $42.3 \pm 2.5^{\mathrm{de}}$ & $55.3 \pm 2.4^{\mathrm{cd}}$ \\
\hline 0.5 & 30 & 10 & $50.2 \pm 1.6^{\mathrm{a}}$ & $24.2 \pm 1.4^{\mathrm{b}}$ & $36.4 \pm 1.5^{\mathrm{a}}$ \\
\hline 0.5 & 30 & 20 & $60.1 \pm 1.5^{\mathrm{c}}$ & $26.8 \pm 1.2^{\mathrm{b}}$ & $40.7 \pm 1.6^{\mathrm{ab}}$ \\
\hline 0.5 & 30 & 30 & $60.4 \pm 2.3^{c}$ & $52.6 \pm 1.4^{\mathrm{f}}$ & $48.6 \pm 2.3^{b c}$ \\
\hline 1.5 & 30 & 10 & $65.5 \pm 1.6^{\mathrm{d}}$ & $25.4 \pm 1.5^{\mathrm{b}}$ & $60.5 \pm 1.5^{\mathrm{de}}$ \\
\hline 1.5 & 30 & 20 & $70.3 \pm 2.4^{\mathrm{e}}$ & $30.2 \pm 1.6^{\mathrm{bc}}$ & $65.2 \pm 1.4^{\mathrm{e}}$ \\
\hline 1.5 & 30 & 30 & $75.2 \pm 1.5^{\mathrm{e}}$ & $48.6 \pm 1.4^{\mathrm{ef}}$ & $68.4 \pm 2.5^{\mathrm{e}}$ \\
\hline Overall mean & 30 & - & $61.9 \pm 1.8^{\mathrm{c}}$ & $33.6 \pm 1.6^{\mathrm{c}}$ & $51.9 \pm 2.1^{\mathrm{c}}$ \\
\hline Fresh sperm & - & - & - & - & $92.5 \pm 1.2^{\mathrm{f}}$ \\
\hline
\end{tabular}

Mean values in a column with different superscripts significantly different $(p<0.05)$.

\section{Discussion}

In the present study, different straw sizes and thawing temperatures conditions were examined with respect to their potential to protect $C$. carpio sperm during freezing and thawing procedure concerning effect on motility, motility period and fertility. On the other hand, comparison of different freezing/thawing protocols are difficult due to many factors effected the ability of sperm to fertilise eggs.

Cryoprotectants can suppress most cryoinjuries when used higher concentrations but at the same time it can become toxic for the sperm cells. The effectiveness of each cryoprotectant varies in different animal species (Velasco-Santamaria et al. 2006). Therefore, an acceptable cryoprotectant density is essential for the proper cryopreservation procedure. In the present study, methanol was tested for the common carp sperm cryopreservation process. Methanol is one of the most common internal permeable cryoprotectant. So, another important reason for the success of higher fertilization results can be linked to the adequate penetration of methanol through cell membranes.
This indicates that methanol has stable protective impact against freezing damage as membrane stabilizer (Yavaş and Bozkurt 2011).

The findings of this study support previous studies of other fish in which optimal postthaw sperm motility and fertilization were achieved using methanol. In this concept, salmonid semen has been cryopreserved more effectively with methanol as the permeable cryoprotectant than with dimethyl sulfoxide (DMSO), glycerol, a DMSO-glycerol mix, 1,2-propanediol, or $\mathrm{N}, \mathrm{N}$-dimethyl acetamide (Lahnsteiner et al. 1996; Lahnsteiner et al. 1997; Lahnsteiner 2000). Similar studies of ictalurid, silurid, and acipenserid semen have also showed improved postthaw motility or fertilization by use of methanol (Tiersch et al. 1994; Horvath and Urbanyi 2000; Glogowski et al. 2002). Also, Yasui et al. (2009) reported the maximum motility and motility duration of post-thawed loach (Misgurnus anguillicaudatus) sperm with methanol. Harvey et al. (1982) found that methanol is nontoxic when used as cryoprotectant in zebrafish. In addition, it has been found superior to DMSO or glycerol in a number of 
cell types including sturgeon spermatozoa (Horvath and Urbányi, 2000). According to Ashwood-Smith (1980), methanol is in capability of penetrating to the cells with extreme rapidity. In addition, Horvath et al. (2003) also reported highest fertilization and hatching rates in common carp eggs inseminated with sperm frozen with glucose and fructose based extenders that's containing methanol as internal permeable cryoprotectant.

Diluted sperm was equilibrated for $10 \mathrm{~min}$ at $4{ }^{\circ} \mathrm{C}$ in this research. Some authors recommend equilibration period which would allow penetration of cryoprotectants to spermatozoa before cryopreservation (Akçay et al. 2004). The use of 0.25 and $0.5 \mathrm{~mL}$ straws for sperm cryopreservation experiments have been widely used. While straws with a volume of $0.5 \mathrm{~mL}$ are suited for gene banking and for freezing of small amounts of semen, straws with a volume of $1.2 \mathrm{~mL}$ have advantages for the fertilization of large egg batches. For this reason, using of large straws would enable the fertilization when it is essential to fertilize large amount of eggs. Straws of larger volumes would be better suited for large scale insemination in aquaculture and adequate straws, freezing and thawing conditions will have to be developed in the future. The post-thaw results determined in the present study suggest that $1.5 \mathrm{~mL}$ straws thawed at $30{ }^{\circ} \mathrm{C}$ are effective for fertilization processes of common carp on a commercial scale.

In the present research, the fertilization was carried out using $1 \times 105$ thawed spermatozoa per egg and the highest fertilization rate was determined as mean $68.4 \pm 2.5 \%$ with frozen semen in $1.5 \mathrm{~mL}$ straws. Munkittrick and Moccia (1984) and Billard (1992) reported that 3x106 frozen sperm per egg require for the successful fertilization. The amount of cryopreserved semen used for fertilization were about 5 to 10 times higher than the amounts of fresh semen used for fertilization due to thawed semen has significant alterations in morphology, physiology and biochemistry (Lahnsteiner et al. 1996). For these reasons, the fertilizing capacity of frozen-thawed spermatozoa was lower than that of fresh sperm that was determined as $92 \%$ in the present study. This situation demonstrates the changings in motility following cryopreservation protocol.

Thawing of sperm is critical to preserve spermatozoa viability and according to Lahnsteiner (2000), thawing rates should be high to avoid recrystallization. The temperature change should allow movement of water and cryoprotectants while preventing intracellular ice recrystallization (Richardson et al. 2011). Although, Lahnsteiner et al. (1999) reported that optimal thawing temperature was $25^{\circ} \mathrm{C}$ for the Cyprinid spermatozoa, successful post-thaw motility and fertilization results were determined in the present study when frozen semen was thawed at $30^{\circ} \mathrm{C}$. Overall, frozen sperm thawed at $30^{\circ} \mathrm{C}$ for 30 second was the optimum condition to obtain a suitable motility duration. Also, according to results it appears that ice crystal formation during thawing were reduced by the present protocol.

The obtained results from this study indicated that using of ionic based extender containing 10\% methanol is qualified for artificial insemination and propagation of common carp with cryopreserved sperm. Based on the results determined in the present research, it is reasonable to suggest for large scale insemination that sperm cryopreserved in $10 \%$ methanol, packed in large-volume straw $(1.5 \mathrm{~mL})$ and thawed at $30{ }^{\circ} \mathrm{C}$ for $30 \mathrm{~s}$ which resulted in $68.4 \pm 2.5 \%$ fertility, are suitable for common carp. The cryopreservation protocol improved in the present research was found highly effective and thus can be used in commercial hatcheries to facilitate artificial reproduction in common carp hatcheries. On the other hand, additional research is needed regarding with effect of extenders, cryoprotectants and freezing techniques on survival and malformations of progeny produced with cryopreserved common carp sperm.

\section{Acknowledgements}

This research was supported by a grant from Mustafa Kemal University Scientic Research Fund (MKU-06-E-0202). The authors also would like to thank the staff of the State Hydraulic Works (SHW) Fish Production Station in Adana (Turkey) for their technical assistance.

\section{References}

Akçay E, Bozkurt Y, Seçer S, Tekin N. 2004. Cryopreservation of mirror carp semen. Turk J Vet Anim Sci. 28(5):837-843.

Alvarez B, Fuentes R, Pimentel R, Abad Z, Cabrera E, Pimentel E, Arenal A. 2003. High fry production rates using post-thaw silver carp (Hypophthalmichtys molitrix) spermatozoa under farming conditions. Aquaculture. 220(1):195-201. doi: 10.1016/S0044-8486(02)00356-3

Ashwood-Smith MJ. 1980. Low-temperature preservation of cells, tissues and organs. In: Ashwood-Smith, M.J., Farrant, J. (Eds.). Low Temperature Preservation in Medicine and Biology. Pitman Medical, Turnbridge Wells, pp. 19-45.

Basavaraja N, Hegde SN. 2004. Cryopreservation of the endangered mahseer (Tor khudree) spermatozoa: I. Effect of extender composition, cryoprotectants, dilution ratio and storage period on post-thaw viability. Cryobiology. 49(2):149-156. doi: 10.1016/j.cryobiol.2004.05.007

Billard R. 1992. Reproduction in rainbow trout: sex differentiation, dynamics of gametogenesis, 
biology and preservation of gametes. Aquaculture. 100(1-3):263-298. doi:10.1016/0044-8486(92)90385-x

Bozkurt Y, Akcay E, Tekin N, Secer S. 2005. Effect of freezing techniques, extenders and cryoprotectants on the fertilization rate of frozen rainbow trout (Oncorhynchus mykiss) sperm. The Israeli Journal of Aquaculture-Bamidgeh. 57(2):125-130. doi: $10524 / 19138$

Cabrita E, Anel L, Herráez MP. 2001. Effect of external cryoprotectants as membrane stabilizers on cryopreserved rainbow trout sperm. Theriogenology. 56(4):623-635. doi: 10.1016/S0093-691X(01)00594-5

Cruz-Casallas PE, Pardo-Carrasco SC, Arias-Castellanos JA, Lombo-Castellanos PE, Lombo-Rodríguez DA, Pardo-Mariño JE. 2004. Cryopreservation of Yamú Brycon siebenthalae milt. J World Aquacult Soc. 35(4):529-535. doi:10.1111/j.1749-7345.2004.tb00120.x

De Graaf JD, Berlinsky DL. 2004. Cryogenic and refrigerated storage of rainbow smelt (Osmerus mordax) spermatozoa. J World Aquacult Soc. 35(2):209-216. doi: 10.1111/j.1749-7345.2004.tb01076.x

Glogowski J, Ciereszko A, Dabrowski K. 1999. Cryopreservation of muskellunge and yellow perch semen. North Am J Aquacult. 61(3):258-262. doi: 10.1577/1548-8454(1999)0612.0.CO;2

Glogowski J, Kolman R, Szczeptowscki M, Horvath A, Urbanyi B, Scieczynski P, Rzemieniecki A, Domagala J, Demianowicz W, Kowalski R, Ciereszko A. 2002. Fertilizing rate of Siberian sturgeon (Acipenser baerii, Brandt) semen cryopreserved with methanol. Aquaculture.211(1):367-373.

doi: 10.1016/S0044-8486(02)00003-0

Harvey B, Kelley RN, Ashwood-Smith MJ. 1982. Cryopreservation of zebra fish spermatozoa using methanol. Can J Zool. 60(8): 1867-1870. doi: $10.1139 / \mathrm{z} 82-242$

Horvath A, Urbanyi B. 2000. Cryopreservation of sterlet (Acipenser ruthenus) sperm. In: Norberg B, Kjesbu OS, Taranger GL, Andersson E, Stefansson SO. (Eds.), Reproductive Physiology of Fish. University of Bergen, Bergen, Norway, pp. 441 p.

Horvath A, Miskolczi E, Urbanyi B. 2003. Cryopreservation of common carp sperm. Aquat. Living Resour. 16(5):457-460. doi:10.1016/S0990-7440(03)00084-6

Lahnsteiner F, Weismann T, Patzner RA. 1996. Cryopreservation of semen of the grayling (Thymallus thymallus) and the Danube salmon (Hucho hucho). Aquaculture. 144(1-3):265-274. doi:10.1016/S0044-8486(96)01308-7

Lahnsteiner F, Weismann T, Patzner RA. 1997. Methanol as cryoprotectant and the suitability of $1.2 \mathrm{ml}$ and $5 \mathrm{ml}$ straws for cryopreservation of semen from salmonid fishes. Aquacult Res. 28(6):471-479. doi: 10.1046/j.1365-2109.1997.00886.x
Lahnsteiner F, Weismann T, Patzner RA. 1998. An efficient method for cryopreservation of testicular sperm of the Northern pike, Esox lucius Linnaeus. Aquacult Res. 29(5):341-347. doi: 10.1046/j.1365-2109.1998.00205.x

Lahnsteiner F, Berger B, Weismann T. 1999. Sperm metabolism of the teleost fishes Chalcalburnus chalcoides and Oncorhynchus mykiss and its relation to motility and viability. J Exp Zool. 284(4):454-465. doi: 10.1002/(SICI)1097-010X(19990901)284:4<454 ::AID-JEZ12>3.0.CO;2-O

Lahnsteiner F. 2000. Semen cryopreservation in the salmonidae and in the northern pike. Aquacult Res. 31(3):245-258. doi: 10.1046/j.1365-2109.2000.00452.x

Linhart O, Rodina M, Cosson J. 2000. Cryopreservation of sperm in common carp: sperm motility and hatching success of embryos. Cryobiology. 41(3):241-250. doi: 10.1006/cryo.2000.2284

Liu QH, Chen YK, Xiao ZZ, Li J, Xu SH, Shi XH. 2010. Effect of storage time and cryoprotectant concentrations on the fertilization rate and hatching rate of cryopreserved sperm in red seabream (Pagrus major Temminck \& Schlegel, 1843). Aquacult Res. 41(9):89-95. doi: 10.1111/j.1365-2109.2009.02466.x

Muchlisin ZA, Hashim R, Chong ASC. 2004. Preliminary study on the cryopreservation of tropical bagrid catfish (Mystus nemurus) spermatozoa; the effect of extender and cryoprotectant on the motility after short-term storage. Theriogenology. 62(1-2):25-34. doi: 10.1016/j.theriogenology.2003.05.006

Munkittrick KR, Moccia RD. 1984. Advances in the cryopreservation of salmonid semen and suitability for a production-scale artificial fertilization program. Theriogenology. 21(4):645-659. doi:10.1016/0093-691X(84)90449-7

Omitogun OG, Olaniyan OF, Oyeleye OO, Ojiokpota C, Aladele SE, Odofin WT. 2010. Potentials of short term and long term cryopreserved sperm of African giant catfish (Clarias gariepinus Burchell 1822) for aquaculture. African J Biotech. 9(41): 6973-6982. doi: 10.5897/AJB09.1680

Rana KJ, McAndrew BJ. 1989. The viability of cryopreserved tilapia spermatozoa. Aquaculture. 76(3-4):335-345.

doi: 10.1016/0044-8486(89)90085-9

Richardson GF, McNiven MA, Mansour N. 2011. Effect of methanol concentration and thaw rate on the viability and fertility of cryopreserved Arctic char, Salvelinus alpinus (L.), spermatozoa. Aquacult Res. 42(8):1096-1100. doi: 10.1111/j.1365-2109.2010.02695.x

Rodina M, Gela D, Kocour M, Hadi SMH, Hulak M, Linhart O. 2007. Cryopreservation of tench, Tinca tinca, sperm: sperm motility and hatching success of embryos. Theriogenology. 67(5):931-940. doi: 10.1016/j.theriogenology.2006.11.007

Steyn GJ, Van Vuren JHJ. 1987. The fertilizing capacity of cryopreserved sharptooth catfish (Clarias gariepinus) sperm. Aquaculture. 63(1-4):187-193. doi: 10.1016/0044-8486(87)90070-6 
Stoss J, Holtz W. 1983. Cryopreservation of rainbow trout sperm: IV. The effect of DMSO concentration and equilibration time on sperm survival, sucrose and $\mathrm{KCl}$ as extender components and the osmolality of the thawing solution. Aquaculture. 32(3-4):321-330. doi:10.1016/0044-8486(83)90229-6

Suquet M, Dreanno C, Fauvel C, Cosson I, Billard R. 2000. Cryopreservation of sperm in marine fish. Aquacult Res. 31(3):231-243. doi: 10.1046/j.1365-2109.2000.00445.x

Tekin N, Seçer S, Akçay E, Bozkurt Y, Kayam S. 2007. Effects of glycerol additions on post-thaw fertility of frozen rainbow trout sperm, with an emphasis on interaction between extender and cryoprotectant. J Appl Ichthyol. 23(1):60-63.

doi:10.1111/j.1439-0426.2006.00792.x

Tiersch, T. R., C. A. Goudie, and G. J. Carmichael. 1994. Cryopreservation of channel catfish sperm: storage in cryoprotectants, fertilization trials, and growth of channel catfish produced with cryopreserved sperm. $\mathrm{T}$ Am Fish Soc. 123(4):580-586.

doi:10.1577/1548-8659(1994)123<0580:COCCSS> 2.3.CO;2

Velasco-Santamaria YM, Medina-Robles VM, Cruz-Casallas PE. 2006. Cryopreservation of yamu (Brycon amazonicus) sperm for large scale fertilization. Aquaculture. 256(1-4): 264-271. doi: 10.1016/j.aquaculture.2006.02.039

Yasui GS, Arias-Rodriguez L, Fujimoto T, Arai K. 2009. A sperm cryopreservation protocol for the loach (Misgurnus anguillicaudatus) and its applicability for other related species. Theriogenology. 116:3-4. doi: 10.1016/j.anireprosci.2009.02.021

Yavaş İ, Bozkurt Y. 2011. Effect of different thawing rates on motility and fertilizing capacity of cryopreserved grass carp (Ctenopharyngodon idella) sperm. Biotechnol Biotec Eq. 25(1): 2254-2257. doi:10.5504/BBEQ.2011.0018 